\title{
Effect Of Education, Promotion Position And Conflict In Organization On Motivation Of Country Civil Work Aparting In Regional Financial Area (B.Keuda) West Sumatera Province
}

\author{
Dwinda Novera ${ }^{1}$, Erni Masdupi ${ }^{2}$, Rosyeni Rasyid ${ }^{3}$ \\ ${ }^{1}$ Universitas Negeri Padang, Padang and Indonesia, $\square$ (e-mail) dw.novera@gmail.com \\ ${ }^{2}$ Universitas Negeri Padang, Padang and Indonesia, $\triangle$ (e-mail) emasdupi@yahoo.com \\ ${ }^{3}$ Universitas Negeri Padang, Padang and Indonesia, $\square$ (e-mail) rosyenirasyid@yahoo.com
}

\begin{abstract}
The purpose of this study was to determine the effect of education, promotion and conflict in the organization on the work motivation of B.Keuda West Sumatera Province. Population in this research all employees of Regional, which is 128 employees. The sampling technique of this research is cluster propotional sampling with slovin formula which means the method of determining the respondents to be sampled based on the work unit so that the total obtained 97 employees as a sample. Data analysis in this research using Structural Equation Modeling (SEM) by using SmartPLS program. The results of this study indicate that: 1) Education has a significant and positive effect on work motivation on the staff of Regional Finance Agency (B.Keuda) West Sumatra Province, 2) Education has a significant and positive impact on promotion to employees of Provincial Finance Board (B.Keuda) West Sumatera, 3) Promotion has a significant and positive effect on work motivation of the staff of Regional Finance Agency (B.Keuda) of West Sumatera Province, 4) Conflict has significant and negative effect on work motivation on the staff of Regional Finance Agency (B.Keuda) West Sumatera Province, and 5) Education has a significant and positive impact on work motivation through the promotion of employment positions B.Keuda West Sumatra Province.
\end{abstract}

Keywords: Job Motivation, Education, Promotion, and Conflict

\section{Introduction}

The paradigm shift of the system of government began to be felt since the enactment of Law No. 22 (1999) on Regional Government, following Law No. 32 (2004) on Regional Government which affirms that regional autonomy is the authority of autonomous regions to regulate and manage regional interests according to the initiative of the region itself based on community aspirations. The change of authority between levels of government as regulated by Law No. 23 (2014) brings certain consequences for the region to carry out its duties and responsibilities. Among the consecutions referred to is the region must be able to finance all government activities and development that become its authority. In line with this Regulation No. 08 (2016) on the Establishment and Composition of Regional Devices of West Sumatra Province, has been formed Regional Financial Agency which generally has the function of managing regional finances that include the management of regional income, regional expenditure and regional financing that all are contained in Regional Revenue and Expenditure Budget (APBD). To carry out its duties and functions then the staff of Regional Finance Agency must have a high work motivation, where the motivation of work is a boost from within a person to carry out activities. Work motivation is suspected to be still problematic in ASN Regional Finance Agency of West Sumatra Province.

Based on the phenomenon that the authors see in the Regional Finance Board of West Sumatra Province seen a problem related to work motivation personnel, especially the desire of employees for 
the need for achievement: First, still find employee who slowly complete the tasks that are the responsibility of employees, this is because often employees wait orders first from superiors and stalling time to deadline limit, the activity of financial reporting of OPD conducted by secretariat section of sub program part, not according to schedule which have been determined according to SOP, if this keep happening then by itself will inhibit and slow down process of preparation of Sumatera Province Financial Report West which should be on time, because the West Sumatera Provincial Finance Report is compiled from each OPD Financial Statement, then on the OPD B. Keuda Work Plans (Renja) activities where Renja OPD B. Keuda is collected from Renja composed by bida ng-field on B. Keuda. Preparation of Renja which is preceded by the request of Renja proposal of the fields is often not according to the time set in SOP then by itself the submission of Work Plan of OPD B. Keuda to Regional Development Planning Board (BAPPEDA) as the leading sector in Preparation of Renja of West Sumatera Province will also experience delays. Likewise with the Budget Division, seen in the activities of Ratification of DPA and DPPA of the WTO which is in line with the Drafting of the Cash Budget Plan, which is not in accordance with the time set in the SOP then by itself will slow the process of ratification of DPA/DPPA OPD itself resulting in the realization of shopping activities OPD is not implemented maximally, then at the activity of Governor Regulation (Pergub) Regulation on Standard of Local Budget which often experience delay in its completion so that OPD there is no standard cost guideline in preparation of APBD Awal activity expense. Furthermore, it is seen in the activities of Administrative Management of the Staff Officers covered by B.Keuda conducted by the secretariat of general subag and staffing, which in the process is often late and not in accordance with the time specified, so that the sending of officers file promotion to West Sumatera Province BKD is also late and resulted in the long decline of the Employee Increase Decree from BAKN.

The phenomenon related to work motivation is also seen in the Regional Finance Board of West Sumatra Province, which is still met by employees who lost to follow-up during work hours such as employees who came late to the office, this is related to the attendance of employees of the Regional Finance Agency of West Sumatra

In order to increase and empower the potential, especially in the organization would need reliable human resources that must be prepared as early as possible through the education path. Education is thought to have an impact or impact on work motivation. Hasibuan (2007: 87), education is defined as the environmental influence of individuals to produce permanent or permanent changes in their behavioral habits, thoughts and attitudes. So education is a dynamic activity in the activities of each individual that affect the physical, mental, emotional and social development. In other words, education is a dynamic activity that affects all aspects of individual personality and life.

Based on the authors' observation, it is suspected that the phenomenon of education of the Regional Finance Agency (B.Keuda) staff is seen in the duration of education and non formal education. In formal education it is concluded that there are still many employees who have length of education under undergraduate that is almost $50 \%$, as already discussed above education is a dynamic activity that affect all aspects of life, if one's education is higher should motivation in work is also higher (Hasibuan, 2007). In non-formal education there are still few employees who follow the non-formal education in the form of technical training task supporters of employees as depicted in table 4 above, in 2 years there was a decrease in the number of employees who follow the technical training which is non-formal education for employees. The least employees who follow the training because of: First, the training is held not in accordance with the needs of employees. Second, the limited availability of budget to send employees to training training. Third, the implementation of the training often coincides with the schedule of density of work volume at the office as at the end of the year.

Work motivation can also be influenced by promotion. According to Susilowati (2008) with the implementation of promotion properly can increase employee motivation. Job promotion is an effort 
by an organization or company to provide an opportunity for employees who have good work performance and generally based on seniority factor (experience/duration of work) to occupy a position higher than the occupation previously occupied and has the authority and responsibility the greater one.

The phenomenon related to promotion that is in the structural position of staff as many as 27 employees do not meet the criteria of promotion requirements either the terms of administration, potential mapping or performance appraisal, as well as the structural position of echelon IV as many as 6 people meet the administrative requirements for promotion but do not meet the requirements of potential mapping and performance appraisals that keep them in the same position for years and are unlikely to get promoted job titles due to near-retirement age. Positions that for years occupied by employees can trigger saturation in the work and later can affect the motivation of employment (Susilowati, 2008: 71).

Promotion of Position is also influenced by education as revealed by Fikri (2001), "The level of education becomes one of the determinants of promotion criteria, because workers who already have higher education are more knowledgeable, smarter and more experienced in terms of insight" . If viewed from the interests of the organization, with the promotion of employment is expected to be able to release the best ability that may have been constrained due to the position or previous position of the employee's authority is still minimal. Besides the promotion of positions are also able to provide opportunities for employees to grow and add new experiences work environment (Pabowo, et al: 2016).

Work motivation is also suspected to be influenced by conflicts in the work environment. Good working conditions and a sense of security can be achieved if within the organization avoid conflict, either inter-personal or inter-group conflict within the organization. In West Sumatra Provincial Finance Board, the conflict intended in this research is First Conflicts of Tasks, interdependence of tasks where between fields need each other, if one field does not complete its work thoroughly and timely can affect the work of other fields. Second, the difference in values and perceptions in which the emergence of negative thinking of employees who assume that the relatively young employees get the job and the job is quite heavy compared with employees who are relatively old and almost entering the retirement age. Third, jurisdictional obscurity where employees feel lack of explanation of work procedures so that employees need to wonder to other colleagues, this can hinder the work that should be quickly resolved.

\section{Methods}

This type of research is descriptive and causative. Population of this research is all employee of B.Keuda Provinsi Sumatera Barat. The sampling technique in this research is cluster proportional sampling so that obtained the number of samples as much as 97 respondents. The types and sources of data in this study used primary data and secondary data. Data collection techniques conducted in this study, namely observations, questionnaires and interviews. Instrument in this research is using questioner with likert scale.

\section{Results and Discussion}

\section{Outer Model/Measurement Model}

This research uses data analysis method using SmartPLS 2.0 software. PLS (Partial Least Square) is a general approach of data analysis in path model or known as path analysis. 


\section{Validity test}

To test the validity of variables with reflective indicators can be seen from the correlation between indicators with variables. Individual indicators will be considered valid or convergent validity, if it has a correlation value above 0.5 (Imam, 2006).

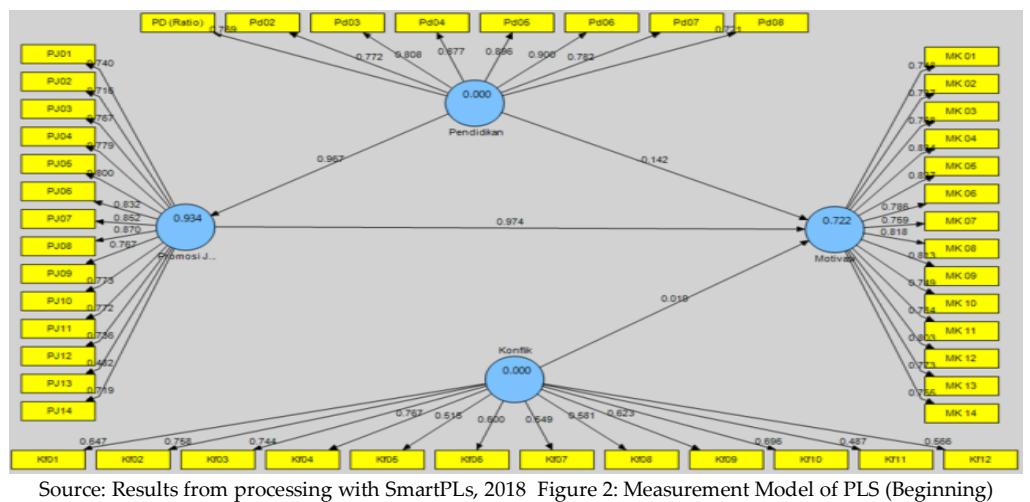

Based on testing with SmartPLS 2.0, the validity test value can be seen in the outer loading table, if the value above $>0.5$ means the value is considered valid and the value below 0.5 is considered invalid. Invalid values are KF11, and PJ13. Invalid values will either be dropped or not included in the next test.

After the invalid value is discarded/re-estimated, finally all data values are valid or above 0.5 can be seen in the following figure:

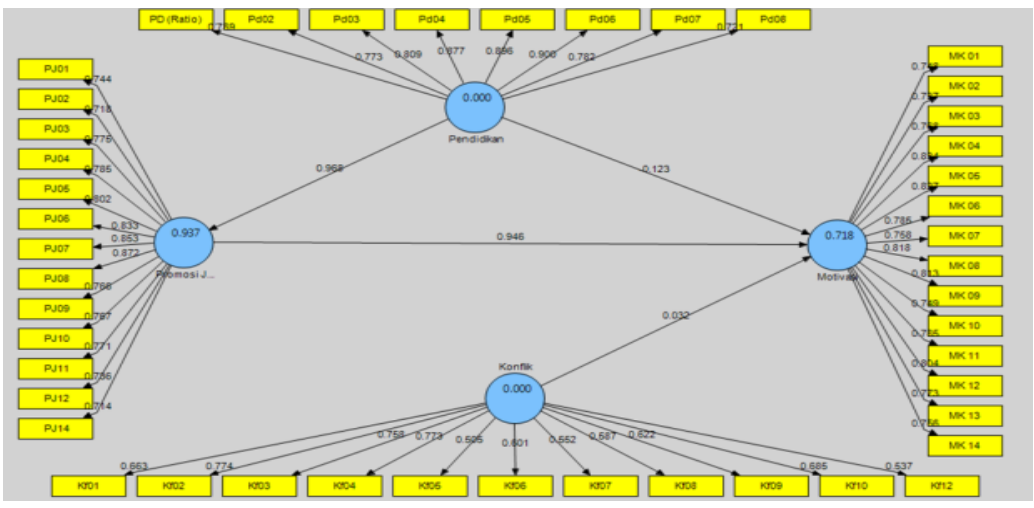

Source: Results from processing with SmartPLs, 2018, Figure 3: Measurement Model of PLS (Re-Estimate)

In addition to seeing the value of outer loading, validity can also be seen on the cross loading to see the value of discriminant validity it, in this study Discriminant validity is said to be high because the correlation indicator with the parent variable is higher than the correlation of the indicator with other variables.

Another method of assessing discriminant validity is to look at the average variance extracted (AVE) for each variable. The indicator of the endogenous and exogenous variables is valid if it has an AVE value of $\geq 0.5$. Here are the AVE tables:

Table 1 Average Variance Extracted Analysis (AVE) results

\begin{tabular}{cc}
\hline Variable & AVE \\
\hline Motivation & 0.613419 \\
\hline Education & 0.604663 \\
\hline Promotion of & 0.610166 \\
\hline Conflict & 0.620083 \\
\hline Source: Results from processing with SmartPLS, 2018
\end{tabular}


Based on the above table it can be concluded that each consonant has a validity above 0.5 . It can be concluded that the indicator of the latent variable has a good degree of validity.

\section{Reliability}

Reliability test is done by looking at the value of composite reliability and cronbachs alpha from block indicator that measure variable. The results of composite reability and cronbachs alpha will show satisfactory values when above 0.7 . Here is the composite reliability of SmartPLS output:

Table 2 Results of data reliability analysis

\begin{tabular}{ccc}
\hline Variable & Composite Reliability & Cronbachs Alpha \\
\hline Motivation & 0.956861 & 0.951380 \\
\hline Eduction & 0.919890 & 0.894222 \\
\hline Promotion of Position & 0.952992 & 0.946379 \\
\hline Conflict & 0.886457 & 0.860880
\end{tabular}

The following table shows that the composite reability value for all constructs is above 0.7 indicating that all indicators of the estimated variables meet the criteria or reliable.

\section{Inner Model}

Inner model or structural model testing is done to see the relationship between variables, significance value and R-square of research model. The structural model is evaluated by using Rsquare to see what percentage influence exogenous variable to endogenous variable and test for significance of latent variable.

\section{R-Square}

Assessment of structural model with PLS begins by looking at R-square on endogenous and exogenous latent variables. Here is the result of R-square estimation using SmartPLS.

Table 3 Results of R-square analysis

\begin{tabular}{cc}
\hline Variable & \multicolumn{1}{c}{ R- } \\
\hline Motivation & 0.7180 \\
\hline Eduction & \\
\hline Promotion of Position & 0.936770 \\
\hline Conflict & \\
\hline Source: Results from processing with SmartPLS, 2018
\end{tabular}

The following table shows the value of the relationship variables that are influenced by the variables that influence it.

\section{Criteria Goodness of Fit}

Goodness of fit is used to know the accuracy of the model with research data. The test result index is compared with the critical frontier value of the goodness of fit criteria. Here the goodness of fit search results:

$$
\begin{aligned}
\mathrm{GOF} & =\sqrt{\mathrm{AVE}} \times \overline{\mathrm{R}^{2}} \\
& =\frac{\sqrt{0,613+0,605+0,610+0,620}}{4} \times \frac{0,718+0,997}{2} \\
& =0,782 \times 0,828 \\
& =0,647
\end{aligned}
$$

Based on the above results, the value of goodness of fit has a medium criterion that is above $>0.38$, thus it can be stated that the results of this test has resulted in a high fit model and good on causal relationships variables that exist in this study. 


\section{Path Coefficient}

The significance of the variable provides very useful information about the relationship between research variables. The basis used in testing the hypothesis is the value found in Path Coefficients. Here's the estimated output for structural model testing.

Table 4 Results of Path coefficients

\begin{tabular}{llllll}
\hline Variable & $\boldsymbol{O}$ & $\boldsymbol{M}$ & STDEV & STERR & (O/STERR \\
\hline PD-> MK & 0.12 & 0.14 & 0.02 & 0.02 & 6.61 \\
\hline PD -> PJ & 0.97 & 0.97 & 0.01 & 0.01 & 19.87 \\
\hline PJ -> MK & 0.95 & 0.95 & 0.21 & 0.21 & 4.53 \\
\hline Kf-> MK & 0.30 & 0.04 & 0.08 & 0.08 & 4.42 \\
\hline \multicolumn{5}{c}{ Source: Results from processing with SmartPLS, 2018 }
\end{tabular}

In the PLS statistical test each hypothesized relationship is performed using a simulation. In this case the bootstrapping method is performed on the sample. Testing with bootstrapping is also intended to minimize the problem of research data abnormalities.

\section{Significance (Hypothesis Testing)}

\section{Hypothesis Testing 1: The Effect of Education Against Motivation.}

The results of the first hypothesis testing showed that the variables of education on work motivation showed the value of path coefficient of 0.12 with $t$-count of 6.61 . The value is greater than the value of $t$-table $(1,96)$ or Ha accepted and Ho rejected. This result means that there is a significant positive influence between the variables of education with work motivation. If the employee of B.Keuda West Sumatera Province has a higher education then the motivation of employees in work is also increasing.

\section{Hypothesis Testing 2: The Influence of Education Against Promotion Position}

Results of testing the second hypothesis shows that the educational variables on promotion shows the value of the coefficient path of 0.97 with $t$-count of 19.87 . The value is greater than the value of $t$ table $(1,96)$ or Ha accepted and Ho rejected. This result means that there is a significant positive influence between education and promotion. If the education undertaken by the employee of B.Keuda of West Sumatera Province is higher, then it is also the opportunity of the employee to get promotion of position.

\section{Hypothesis Testing 3: The Effect of Promotion on Work Motivation.}

The result of the third hypothesis testing shows that the promotion variable on work motivation shows the coefficient value of the path of 0.95 with the $t$-count of 4.53 . The value is greater than the value of t-table $(1,96)$ or Ha accepted and Ho rejected. This result means that there is a significant positive influence between promotion and work motivation. If the employee of B.Keuda of West Sumatera Province get promotion promotion then his motivation in work will increase.

\section{Hypothesis Testing 4: The Influence of Conflict Against Motivation.}

The result of the fourth hypothesis test shows that the variable of conflict on work motivation shows the coefficient value of the path of 0.30 with $t$-count of 4.43 . The value is greater than the value of t-table $(1,96)$ or Ha accepted and Ho rejected. This result means that there is a significant negative effect between conflict and work motivation. If the employee of B.Keuda of West Sumatera Province experiences conflict in their work environment, it can trigger the decrease of the employee's motivation in working. 


\section{Hypothesis Testing 5: Effect of Education on Job Motivation Through Promotion Position (Role of Mediating Variables).}

The role of mediator is to prove the direct and indirect influence between variables, namely the influence of education on work motivation with promotion of position as a mediator variable. To prove this indirect relationship is used sobel test (sobel test).

\section{The Influence of Education on Work Motivation.}

Employees who have formal education, non-formal and informal who have high intellectual tend to have a high motivation in working as well, this is because the employee feel the need to procrastinate the work, because the more work is postponed it will increasingly pile up the work so that employee work becomes rush and origin is finished so that the results of the work does not satisfy all parties. Based on the results of the study using SmartPLS 02 program, it is found that education has a significant and positive effect on employee motivation B.Keuda West Sumatera Province.

The results of this study are also in accordance with previous research conducted by Hitka \& Balazova (2016) conducted on 50 employee random samples in Zvolen City, Slovakia, using the same analytical technique that is the result of the analysis path Educational employees in Slovakia are very influential on their motivation in work.

This finding is also reinforced by the theory according to Sedarmaryanti (2001) education in various programs have an important role in the process of obtaining and improving the quality of individual professional skills. Through education, a person is prepared to have a stock to be ready to know, recognize, and develop methods of thinking systematically in order to solve problems that will be faced in later life and increase motivation in work. In addition, Simanjuntak, in Susilowati (2008) explains that education provides knowledge not only directly with the implementation of the task, but also the basis for self-development and the ability to utilize all the means around us for the smooth execution of tasks. The higher the education, the higher the motivation and productivity, it can be concluded that the higher the education obtained someone the higher the work motivation so that the work productivity will be better.

\section{The Influence of Education Against Promotion Position}

Highly educated employees in the formal, informal and informal categories have a great opportunity to gain promotions in addition to the skills they need to have. Based on the results of the study using SmartPLS 02 program, it is found that education has a significant and positive impact on the promotion of employee B.Keuda West Sumatera Province.

The results of this study are also in accordance with previous research conducted by Costantino (2014) in New Jersey State Police with path analysis techniques that the result is All types of education have a significant effect on promotion. In addition, Fikri (2001) also conducted a similar study on Pertamina Apep Mojang employees whose education and training results have a significant effect on promotion of Pertamina Apep Mojang employee position.

This finding is also reinforced by the theory according to Hasibuan (2002), one of the promotional requirements is education, where employees must have a certificate and formal education in accordance with promotional specifications. According to Alex (2002: 112-113), to undertake the promotion of the office of the organization shall establish the conditions in advance which can ensure that the employee to be promoted is like the level of education, that with higher education can be expected to have better thinking.

\section{The Influence of Promotion Position on Work Motivation}

Promotion of office can trigger the increase of work motivation of officer if promotion of job done in fair and transparent, as well as employee of B. Keuda of West Sumatera Province. Based on result 
of research using SmartPLS 02 program, it is found that promotion has significant and positive effect to work motivation of employee B. Keuda West Sumatera Province found that promotion has a significant and positive effect on employee motivation of B. Keuda of West Sumatera Province because $t$-count value is greater than $t$-table that is $4.53>1.96$ so Ha is accepted and Ho is rejected. From the distribution of promotional frequency with the total average score of the promotional variables is 3.73 with TCR $74.55 \%$, This means the promotion of employee B. Keuda West Sumatra Province is already in the "Good" category. Although already in the category of "Good. While the frequency distribution of work motivation variable with the total average score of the motivation variable is 3.78 with TCR 75,55. This means the indicator of need for achievement, the need for affiliation and the need for personnel power B. Keuda West Sumatera Province is already in the "Good" category, although the work motivation is in the "Good" category should the work motivation of employee B. Keuda West Sumatra Province need to be improved again especially in the promotion, should be done with fair campaign so as to increase employee motivation in work.

This finding is also reinforced by the theory according to Susilowati (2008), every employee is basically very eager to get the opportunity promoted. The promoted employees will gain higher social status and compensation (wage/salary receipts) greater than they earned in their previous positions, so that employees will feel valued for their efforts for the organization. Based on the description of the researcher can conclude that with the promotion of office, employees will be more motivated again to work optimally. Promotion is an opportunity for employees to grow and advance and more excited in doing their work so as to increase productivity and efficiency work.

The results of this study is also in accordance with previous research conducted by Pabowo, et al (2016) on employees Telkom Witel West Sumatra which the result is Promotion have a significant effect on work motivation.

\section{The Influence of Conflict Against Work Motivation}

Conflict is a conflict that arises between one individual with another individual or with a group. The emergence of an unresolvable conflict can be an obstacle for someone to do every activity. Especially conflicts of work, if the work conflict cannot be solved later can disrupt the motivation in work. Similarly, employee B.keuda West Sumatera Province, with the results of research using SmartPLS 02 program, it is found that the conflict has a significant and negative impact on employee motivation B.Keuda West Sumatera Province, with such leaders should find the best solution to resolve the conflict so that employee motivation B.Keuda West Sumatra Province did not decrease.

The results of this study are also in accordance with previous research conducted by Nurini (2006) on the staff of Karanganyar District Culture Office with the technique of path analysis which resulted in conflict negatively affect the work motivation of the employee of the Department of Culture of Karanganyar Regency.

These findings are also reinforced by Bernard's theory in Sutaryadi (2001) says several factors related to the inner mood or feelings of pleasure or displeasure, conflicts with superiors and coworkers, excited or not enthusiastic, passionate or unenthusiastic may affect one's motivation in work. According to Gibson in Mohyi (2013) argues that the source of conflict that comes from the workplace either with superiors or with colleagues can create awkwardness to interact actively in the workplace and lower the level of motivation in work.

\section{The Influence of Education on Job Motivation Through Promotion Position}

The last discussion aims to see the indirect influence of promotional variable position as a mediator variable used Sobel calculation (Sobel test). The test results show the estimate value of indirect effect of $91.6 \%$. The result of $t$-total of direct and indirect influence of education variable to work motivation through promotion is $1.039(0,123+0,916)$ bigger than direct influence that is 0,123 only. This indicates that the increase of work motivation is triggered by education owned by an 
employee, in addition if the employee education has been considered good then the job promotion opportunities are also greater, so the employee's work motivation will increase even more.

This finding is in line with the research conducted by Nurini (2006) on the staff of Culture Department of Karanganyar Regency which the result is the variable of education have positive and significant effect to the work motivation through the promotion variable, so that the work motivation of the employee is more increasing than the education only affects the work motivation.

\section{Conclusions}

Based on the results of the overall analysis, it can be concluded that the variables of education, promotion, and conflict affect the motivation of work. This means to increase the motivation of employee of B.Keuda of West Sumatera Province to have higher education and follow nonformal education in the form of training, besides promotion of position must be uniform and fair applied to all employees so as not to interfere with employee work motivation, and the leader must manage conflict which occurs in the employee for employee motivation in work will not decrease.

It is expected that the superior/head of the Regional Financial Agency should pay more attention to the education of the employees, whether the length of education, non formal education or informal education, should be given more opportunity for the employees to continue their education at higher formal level and non formal education programs such as sending more B. Keuda to follow the tasks of employee training so that the motivation of employee work is also increasing, although in this research TCR is in the category of "Good", that is by monitoring indicators of employee education variable. Educational variables not only affect employee motivation but also become one of the important requirements for employees to be promoted higher positions. Promotion of positions that will be given later can trigger an increase in employee motivation in work, if the promotion of the job is felt fair and right for employees.

In addition, the head of the Regional Finance Board of West Sumatra Province should also pay attention to the conflicts that arise among its employees, such as the leadership to bring the two parties in conflict and find a solution or a way out of the problem that is being experienced, that is fair without a personal side/field in conflict. Furthermore, the leadership must always coordinate between fields, because the work done by employees in B. Keuda West Sumatra Province are interrelated between these fields. This is done is to minimize the misunderstanding in the work that led to the occurrence of work conflicts for employee motivation B. Keuda West Sumatra Province does not decrease.

\section{References}

Ardana, I Komang, et al. (2012). Manajemen Sumber Daya Manusia. Yogyakarta: Graha Ilmu.

Badan Keuangan Daerah. (2016). Modul: Dinas Pengelolaan Keuangan Daerah Provinsi Sumatera Barat. Padang: Direktorat Jendral Cipta Karya.

Constantino, David.D. (2014). The Influence of Higher Education on Promotional Outcomes in the New Jersey, State Police: Theses Seton Hall University.

Fikri, Fahmi. (2001). Pengaruh pendidikan dan pelatihan serta promosi jabatan terhadap motivasi kerja di Pertamina Apep kamojang. Proceeding Of The 5TH Inaga Annual Scientific Conference \& Exhibitions Yogyakarta.

Hadari, Nawawi. (2003). Kepemimpinan Mengefektifkan Organisasi. Yogyakarta: Gadjah Mada University Press.

Ghozali, Imam .(2006). Aplikasi Analisis Multivariate dengan Program SPSS. Badan Penerbit Universitas Diponegoro. 
Hasibuan, Malayu. (2007). Manajemen Organisasi Dan Motivasi Dasar Peningkatan Produktivitas. Jakarta :BumiAksara.

Mohyi, Ach. (2013). Teori dan Perilaku Organisasi. Malang: UMM Press.

Nitisemito. A. S. (2002). Manajemen Personalia Edisi Revisi. Jakarta: Ghalia Indonesia.

Nurini, Retno, Hartati. (2006). Analisis pengaruh pendidikan, kompensasi, promosi, dan konflik dalam organisasi terhadap motivasi kerja di dinas pendidikan dan kabupaten Karanganyar. Jurnal Universitas Muhammadiyah Surakarta, 26(1).

Pabowo B et al. (2016). Pengaruh promosi jabatan terhadap motivasi kerja dan prestasi kerja (studi pada karyawan PT Telkom witel Jatim Selatan Malang). Jurnal Administrasi Bisnis (JAB), 32 (1).

Rivai, Veithzal. (2013). Manajemen Sumber Daya Manusia untuk Perusahaan. Jakarta: Raja Grafindo Persada.

Robbins, Stephen .P. (2002). Psikologi Organisasi, (Edisi ke-8). Jakarta: Prenhallindo.

Slameto. (2010). Belajar \& Faktor-Faktor yang Mempengaruhi. Jakarta: Rineka Cipta.

Sutaryadi. (1990). Administrasi Pendidikan. Surabaya: Usaha Nasional.

Susilowati. 2008. Dampak kepemimpinan dan lingkungan kerja terhadap semangat kerja. Jurnal $J R B I, 1(1)$. 